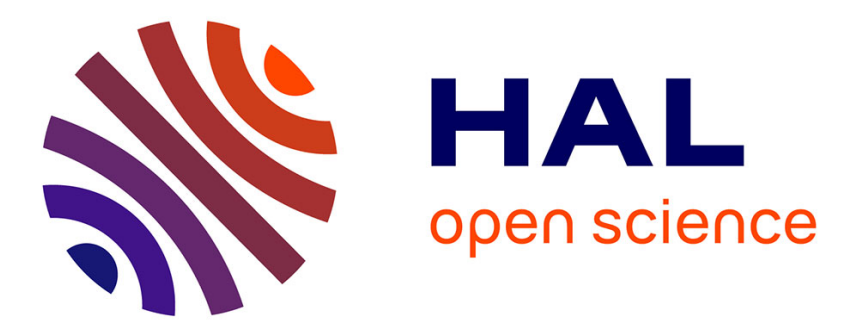

\title{
Hydrodynamic gene delivery in human skin using a hollow microneedle device
}

M. Dul, M. Stefanidou, P. Porta, J. Serve, C. O'Mahony, Bernard Malissen, S. Henri, Y. Levin, E. Kochba, F. S. Wong, et al.

\section{- To cite this version:}

M. Dul, M. Stefanidou, P. Porta, J. Serve, C. O'Mahony, et al.. Hydrodynamic gene delivery in human skin using a hollow microneedle device. Journal of Controlled Release, 2017, 265 (SI), pp.120-131. 10.1016/j.jconrel.2017.02.028 . hal-01764681

\section{HAL Id: hal-01764681 \\ https://hal-amu.archives-ouvertes.fr/hal-01764681}

Submitted on 25 Oct 2018

HAL is a multi-disciplinary open access archive for the deposit and dissemination of scientific research documents, whether they are published or not. The documents may come from teaching and research institutions in France or abroad, or from public or private research centers.
L'archive ouverte pluridisciplinaire HAL, est destinée au dépôt et à la diffusion de documents scientifiques de niveau recherche, publiés ou non, émanant des établissements d'enseignement et de recherche français ou étrangers, des laboratoires publics ou privés. 


\title{
Hydrodynamic gene delivery in human skin using a hollow microneedle device
}

\author{
Dul M ${ }^{\mathrm{a}}$, Stefanidou $\mathrm{M}^{\mathrm{a}}$, Porta $\mathrm{P}^{\mathrm{a}}$, Serve ${ }^{\mathrm{a}}$, O'Mahony $\mathrm{C}^{\mathrm{d}}$, Malissen $\mathrm{B}^{\mathrm{e}}$, Henri S ${ }^{\mathrm{e}}$, Levin $\mathrm{Y}^{\mathrm{c}}$, Kochba $\mathrm{E}^{\mathrm{c}}$, Wong FS ${ }^{\mathrm{b}}$, \\ Dayan $\mathrm{C}^{\mathrm{b}}$, Coulman $\mathrm{SA}^{\mathrm{a}, *}$, Birchall $\mathrm{JC}^{\mathrm{a}}$ \\ ${ }^{a}$ Cardiff School of Pharmacy and Pharmaceutical Sciences, Cardiff University, Cathays Park, Cardiff CF10 3NB, UK \\ b School of Medicine, Cardiff University, Cardiff, UK \\ c NanoPass Technologies, Israel \\ d Tyndall National Institute, Lee Maltings, University College Cork, Cork, Ireland \\ e Centre d'Immunologie de Marseille-Luminy, Aix Marseille Université, Inserm, CNRS, Marseille, France
}

Keywords:

Microneedles

Human skin

DNA

Genetic vaccine

Gene therapy

Hydrodynamic

\begin{abstract}
A B S T R A C T
Microneedle devices have been proposed as a minimally invasive delivery system for the intradermal administration of nucleic acids, both plasmid DNA (pDNA) and siRNA, to treat localised disease or provide vaccination. Different microneedle types and application methods have been investigated in the laboratory, but limited and irreproducible levels of gene expression have proven to be significant challenges to pre-clinical to clinical progression. This study is the first to explore the potential of a hollow microneedle device for the delivery and subsequent expression of pDNA in human skin. The regulatory approved MicronJet600® (Micronjet hereafter) device was used to deliver reporter plasmids ( $\mathrm{pCMV} \beta$ and $\mathrm{pEGFP-N1)}$ into viable excised human skin. Exogenous gene expression was subsequently detected at multiple locations that were distant from the injection site but within the confines of the bleb created by the intradermal bolus. The observed levels of gene expression in the tissue are at least comparable to that achieved by the most invasive microneedle application methods e.g. lateral application of a microneedle. Gene expression was predominantly located in the epidermis, although also evident in the papillary dermis. Optical coherence tomography permitted real time visualisation of the sub-surface skin architecture and, unlike a conventional intradermal injection, Micronjet administration of a $50 \mu \mathrm{L}$ bolus appears to create multiple superficial microdisruptions in the papillary dermis and epidermis. These were co-localised with expression of the $\mathrm{pCMV} \beta$ reporter plasmid. We have therefore shown, for the first time, that a hollow microneedle device can facilitate efficient and reproducible gene expression of exogenous naked pDNA in human skin using volumes that are considered to be standard for intradermal administration, and postulate a hydrodynamic effect as the mechanism of gene delivery.
\end{abstract}

\section{Introduction}

Intradermal delivery of plasmid DNA ( $\mathrm{pDNA}$ ) has been proposed for a number of therapeutic applications $[1,28]$, including DNA vaccines, which are targeted to the skin to exploit the highly evolved and competent local immune system [40,62]. However, although detectable expression of exogenous genes in human and animal skin was achieved over 20 years ago [30-32,85], clinical translation has been hindered by extra- and intra-cellular barriers to efficient and reproducible cell transfection.

Cell barriers to transfection have been well characterised in numerous cell types, including skin cells. Viral vectors enable efficient and long-term expression of exogenous genes [33] but they have a number

\footnotetext{
* Corresponding author.

E-mail address: coulmansa@cardiff.ac.uk (S.A. Coulman).
}

of acknowledged constraints [7,45,51,70]. Non-viral vectors provide an alternative, but whilst these vectors are comparably safe, not immunogenic, low cost and easy to manufacture [43,77], their transfection efficiency is often significantly reduced compared to their viral counterparts [29,53]. Physical enhancement techniques have also been used promote cell transfection. These include electroporation $[9,16,25,63]$, iontophoresis $[8,73]$, particle bombardment $[38,84]$, tattooing [2,59], ultrasound [54] and radiofrequency ablation [4]. However these approaches are limited by the complexity and cost of the equipment, cell death and restricted access to the tissue or organ of interest [48]. The challenge of gene delivery at the cellular level is compounded in the skin, where a diverse range of cell populations exists in a complex three dimensional architecture. The most attractive target for localised gene expression in this stratified organ is the region with the greatest density of viable proliferating cells, i.e. the basal layer of the viable epidermis. This target layer exists 100- 
$200 \mu \mathrm{m}$ below the skin surface and is sandwiched by the terminally differentiating keratinocytes of the upper epidermis and the underlying connective tissue of the dermis. Potential targets for nucleic acid therapies also exist in the elastin and collagen packed layer of the dermis but cells in this region are not constrained to a membranous organisation and are often motile. Overcoming the physical and biological barriers of the skin, which has evolved to act as a barrier to exogenous materials and insults, to target exogenous nucleic acids to specific cell types is therefore challenging.

Despite these challenges, numerous studies have demonstrated that vectorless (naked) pDNA can transfect cells in both human and animal skin $[12,30,31,83]$. This has been traditionally achieved via conventional intradermal injection, whereby a single hypodermic needle with millimetre dimensions is used to overcome the stratum corneum barrier and transfer a bolus of pDNA into the skin. However the resulting gene expression levels are low and often restricted to the viable epidermal cells that surround the injection site [31]. This relatively inefficient method of delivery has therefore been augmented by physical transfection methods, such as electroporation $[9,79]$, which temporarily permeabilises cell membranes to enhance transfection levels in the tissue. Recent advances in this area, including Phase 2 clinical trial data [71], are very encouraging. However conventional injections combined with electroporation have acknowledged limitations e.g. pain, bleeding and the inherent costs and complexity associated with electroporation technology. The ideal delivery system would therefore be a single and simple minimally invasive device [50] that can achieve vectorless delivery of nucleic acids across both the tissue barrier, the stratum corneum, and the major cellular barrier, the cell membrane [34].

Microneedle (MN) technology uses single or multiple microscopic needles to deliver therapeutic materials through the stratum corneum (SC) barrier into the underlying viable epidermis, or dermis, in a minimally invasive manner. The primary advantage of MNs, compared to other 'physical' delivery methods, is the simplicity of the device. Studies have exemplified the potential of MNs for delivery of nucleic acids, both pDNA and siRNA, for the treatment of genetic skin diseases, cutaneous cancers, hyperproliferative diseases and vaccinations and these are summarised in a recent review [47]. These studies have employed solid MNs to deliver pDNA into the skin using either the "soak and poke" $[3,12,60,83]$ or the "coat and poke" approach $[14,22,24,36,61$, $66]$. The former involves topical application of a liquid pDNA formulation prior to application of a MN device [60]. The "soak and poke" method results in reasonable levels of gene expression $[3,11,12,60,83]$ however it is impossible to control the delivered dose using this method. The alternative strategy is to "coat and poke" i.e. a MN device is dry coated with a pDNA formulation and then applied to the skin $[14,24,61]$. MN coating methods are able to control the spatial distribution and mass of a therapeutic that is loaded onto MNs and thus dosing is more reproducible for the coat and poke approach [36]. However the transfection efficiency of this method is significantly reduced [61]. Both of these approaches suffer from low to moderate levels of gene expression that are restricted to cells adjacent to the site of microdisruption. Transfection can be heightened by increasing tissue disruption using repeated MN applications to the skin surface [83] or lateral application of MNs [49]. However, these approaches cause significant disruption of the tissue barrier that are unlikely to be clinically acceptable.

The hollow MN approach administers the therapeutic cargo in a liquid formulation through one or more needles of micron dimensions. The advantages of hollow MN systems are conferred by its ability to inject a finite dose using a standard syringe and with minimal training. Reformulation of commercially available medicines and vaccines is often not required and therefore the potential of hollow MNs has been established both pre-clinically and clinically $[13,26,27,35,41,42,57,64$, $72,76]$. To the best of our knowledge, the ability of hollow MNs to deliver nucleic acids to human skin has not yet been reported. The aim of this study was to investigate the potential of a regulatory approved hollow
MN device, Micronjet [42], for pDNA delivery to human skin in an effort to combine the favourable transfection efficiencies previously witnessed with liquid delivery (soak and poke approach) with the finite dosing that can be achieved using a hollow MN delivery system.

\section{Materials and methods}

All reagents and laboratory consumables were purchased from Fisher Scientific, UK (Loughborough, UK), unless otherwise indicated.

\subsection{Ethics statement}

Human skin samples were obtained from female patients undergoing breast reduction surgery or mastectomy under informed written patient consent and local ethical committee approval (South East Wales Research Ethics Committees Panel C, Reference: 08/WSE03/55).

\subsection{MN characterisation}

The hollow MN devices (MicronJet) used in this study was provided by NanoPass Technologies Ltd. The device consists of an array of three MNs, each $600 \mu \mathrm{m}$ in length, bonded to the tip of plastic adapter, which could be mounted on a standard hypodermic syringe. The needles were fabricated from silicon using MEMS (Micro Electro Mechanical Systems) technology [72]. MicronJet MNs were visualised using a Stemi 2000-C Stereomicroscope (Zeiss, Welwyn Garden City, UK).

\subsection{Preparation of $p D N A$}

The reporter plasmids pCMV $\beta$ and pEGFP-N1 were amplified and purified from previously transformed stocks of DH5 $\alpha$ Escherichia coli using antibiotic selective conditions and a Qiagen Mega Kit (Qiagen Ltd., Crawley, UK), [3].

The pIRES-TdTomato plasmid was obtained from Clontech. Plasmid propagation and purification was performed using a Qiagen Mega Kit ( $p C M V \beta$ and pEGFP-N1) or Qiagen HiSpeed Midi Kit (pIRES-TdTomato plasmid) (Qiagen Ltd., Crawley, UK).

\subsection{Collection, processing and maintenance of an ex vivo human skin}

Excised human breast skin was collected immediately after surgery and transported to the laboratory in culture media, which consisted of Dulbecco's Modified Eagle Medium (DMEM), supplemented with 100 units $\mathrm{mL}^{-1}$ of penicillin and $100 \mu \mathrm{g} \mathrm{mL}^{-1}$ of streptomycin (all Life Technologies, UK) at $4{ }^{\circ} \mathrm{C}$. Collected skin samples were used within $2 \mathrm{~h}$ of excision. Subcutaneous adipose tissue was removed by blunt dissection and skin was pinned, dermis side down, onto a cork dissection board to facilitate injection. An $8 \mathrm{~mm}$ biopsy punch was used to isolate areas of treated skin, which were further maintained in the organ culture by incubating at the air-liquid interface at $37^{\circ} \mathrm{C}$ in an atmosphere of $5 \%(\mathrm{v} / \mathrm{v}) \mathrm{CO}_{2} / 95 \%(\mathrm{v} / \mathrm{v})$ air [55]. Data in this study was obtained from replicate samples obtained from ten independent skin donors (aged 51-80 years old).

\subsection{Gene expression in primary and continuous human keratinocyte cell} lines

\subsubsection{HaCaT cell culture}

Immortalised human keratinocyte cells (HaCaT cells), [6] were received as a gift from Professor Mark Gumbleton (School of Pharmacy and Pharmaceutical Sciences, Cardiff University). Cells were cultured in a growth medium, which consisted of DMEM, supplemented with $10 \%$ fetal bovine serum (FBS), 100 units $\mathrm{mL}^{-1}$ of penicillin and $100 \mu \mathrm{gL} \mathrm{m}^{-1}$ of streptomycin (all Life Technologies, UK) at $37^{\circ} \mathrm{C}$ in a humidified atmosphere containing $5 \% \mathrm{CO}_{2}$. 


\subsubsection{Primary keratinocytes isolation and culture}

Superficial skin tissue was mechanically isolated from a full thickness skin sample using a surgical blade (approx. $1 \times 1 \mathrm{~cm}^{2}$ ) and transferred to a $0.25 \%$ trypsin solution which was incubated overnight at $4{ }^{\circ} \mathrm{C}$. The resulting suspension of cells was filtered through a $70 \mu \mathrm{m}$ cell strainer and centrifuged at $300 \times g$ for $7 \mathrm{~min}$. The cell pellet was gently re-suspended in media (EpiLife medium supplemented with $10 \%$ human keratinocyte growth supplement (HGKS) and 100 units $\mathrm{mL}^{-1}$ penicillin, $100 \mu \mathrm{g} \mathrm{mL} L^{-1}$ of streptomycin and $2.5 \mu \mathrm{g} \mathrm{mL}-1$ of amphotericin B (all Life Technologies, UK) before seeding in a $25 \mathrm{~cm}^{2}$ flask. Growth media was changed every 2-3 days until the primary keratinocytes reached $70-80 \%$ confluence.

\subsubsection{HaCaT cell transfection}

Twenty four hours before treatment, cells were seeded into 24well plates at a density of $7.5 \times 10^{4}$ cells $\mathrm{cm}^{-2}$ in $0.5 \mathrm{~mL}$ growth media. Cell populations were then treated using either (i) naked plasmid (pEGFP-N1 or pIRES-TdTomato) or (ii) pDNA lipoplex formed with Lipofectamine2000 transfection reagent (positive control). Naked plasmid ( $0.6 \mu \mathrm{g}$ in $100 \mu \mathrm{L}$ PBS) was added to a well containing $500 \mu \mathrm{L}$ of DMEM. Transfection complexes were prepared according to the manufacturer's protocol (Life Technologies, UK). Briefly, $2 \mu \mathrm{L}$ of Lipofectamine2000 was diluted in $50 \mu \mathrm{L}$ of DMEM and pDNA ( $0.6 \mu \mathrm{g} /$ well $)$ was diluted in $50 \mu \mathrm{L}$ of DMEM. After $5 \mathrm{~min}$ of incubation, pDNA and Lipofectamine2000 dilutions were mixed gently and allowed to equilibrate for $20 \mathrm{~min}$ at room temperature. Cells were washed once with PBS, and then lipoplexes $(100 \mu \mathrm{L})$ were added to each well containing $500 \mu \mathrm{L}$ of DMEM and mixed gently by rocking the plate back and forth. After $6 \mathrm{~h}$, the cells were washed three times with PBS and the treatment media was replaced with DMEM supplemented with $10 \%$ FBS and the cells were incubated for a further $42 \mathrm{~h}$. All experiments were performed at least in triplicate.

\subsubsection{Primary keratinocyte cell transfection}

Primary keratinocyte transfection was performed in a comparable manner to HaCaT transfection (Section 2.5.3), with the following exceptions. Twenty four hours before treatment cells were seeded into 24well plates at a density of $5 \times 10^{4}$ cells $\mathrm{cm}^{-2}$ in $0.5 \mathrm{~mL}$ growth media. pDNA lipoplexes were prepared in EpiLife media and cells were treated as detailed in Section 2.5.3. After $6 \mathrm{~h}$ the treatment was removed and the cells were washed three times with PBS. EpiLife media, supplemented with $10 \%$ HGKS, was then added to the cell populations which were incubated for a further $42 \mathrm{~h}$. All experiments were performed at least in triplicate.

\subsubsection{Examining gene expression in vitro}

Following a $42 \mathrm{~h}$ incubation period (Sections 2.5.3 and 2.5.4), cell populations were washed three times with PBS before addition of EpiLife imaging media (Life Technologies, UK) to permit live cell imaging. The presence of GFP and TdTomato in cell monolayers was visualised using the Leica DM IRB epifluorescence microscope and imaging system (Leica Microsystems Ltd., UK). The transfection efficiency of pEGFP-N1 and pIRES-TdTomato was determined by flow cytometry using the FACSVerse flow cytometry system (BD Biosciences, UK). To prepare for FACS analysis cells were washed with PBS and then treated with trypsin-EDTA at $37{ }^{\circ} \mathrm{C}$ for $10 \mathrm{~min}$. The cell suspension was then re-suspended in growth medium, centrifuged (Thermo Fisher Scientific, UK) at $300 \times g$ for 5 min and washed with PBS. Pelleted cells were fixed with $100 \mu \mathrm{L}$ of fixation buffer (BD Biosciences, UK) for $15 \mathrm{~min}$ at $4{ }^{\circ} \mathrm{C}$, washed and re-suspended in $200 \mu \mathrm{L}$ of staining buffer (BSA), (BD Biosciences, UK) before flow cytometry analysis. GFP fluorescence was detected using a 527/32 filter, whilst TdTomato used a 568/42 filter (PE channel). On each sample, a minimum of 10,000 events was collected. Analysis of collected data was performed with the FlowJo Flow Cytometry Analysis Software for Mac
Version 10. (Tree Star Inc., USA). The percentage of gated cells in each sample indicates the percentage of fluorescent cells.

\subsection{MN mediated delivery of pDNA in vitro}

Twenty four hours before transfection HaCaT cells were seeded into 24 -well plates at density of $7.5 \times 10^{5}$ cells $\mathrm{cm}^{-2}$ in $0.5 \mathrm{~mL}$ growth media. Cell populations were then treated using: (i) naked plasmid (pEGFP-N1; $5 \mu \mathrm{g} /$ well) injected into the media by pipette, (ii) naked plasmid (pEGFP-N1; $5 \mu \mathrm{g} /$ well) injected into the media by MNs and (iii) pDNA lipoplex (pEGFP-N1; $5 \mu \mathrm{g} /$ well) formed with Lipofectamine2000 transfection reagent (prepared according supplier's recommended protocol) as a positive control. Transfection was performed using a comparable protocol to that described in Section 2.5.3. The transfection efficiency of pEGFP-N1 in cells was determined by fluorescent microscopy and flow cytometry (Section 2.5.5).

\subsection{Gene expression in ex vivo human skin}

\subsubsection{Conventional and MN injection of pDNA into human skin}

Following collection and preparation of excised skin (Section 2.4) $50 \mu \mathrm{L}$ of pDNA ( $\mathrm{pCMV} \beta$ and pEGFP-N1) diluted in PBS, at a range of concentrations (detailed in results), was injected into the tissue using MicronJet MNs or a traditional hypodermic needle (BD Microlance $\left.3,26 \mathrm{G} \times 3 / 8^{\prime \prime}\right) .50 \mu \mathrm{L}$ of PBS was injected as a negative control. Following MN injection, the treatment sites were excised using $8 \mathrm{~mm}$ biopsy punches and incubated for $24 \mathrm{~h}$ at the air-liquid interface at $37^{\circ} \mathrm{C}$ and $5 \%(\mathrm{v} / \mathrm{v}) \mathrm{CO}_{2} / 95 \%(\mathrm{v} / \mathrm{v})$ air. Injections were performed at least in triplicate.

\subsubsection{Lateral MN disruption of human skin}

Split-thickness human skin was pinned onto a cork dissection board (Section 2.4). $20 \mu \mathrm{L}$ of pDNA solution (pCMVß) at concentration of $3.5 \mathrm{mg} / \mathrm{mL}$ was applied to the skin surface. A $4 \times 4$ array of MN-like structures, manufactured using silicon wet etching techniques [81], was provided by the Tyndall National Institute. In this instance the wafer was removed from the etchant early in order to leave a flat uppermost surface, Fig. 8D (inset), instead of the nmsharp tip associated with conventional microneedles [58]. The flat tip of this truncated conical structure (more accurately termed a frustum tip) helps to enhance the skin disruption and maximise reliability when scraped laterally across the skin surface. This array was then applied in a downward motion to the edge of the treated area, under constant pressure, for a period of approximately $2 \mathrm{~s}$ and subsequently moved laterally across the skin surface.

\subsubsection{Examination of plasmid expression in ex vivo human skin}

2.7.3.1. $\beta$-Galactosidase enzyme detection. Twenty four hours after treatment, all samples were rinsed in PBS for $30 \mathrm{~min}$, and fixed in $2 \%$ glutaraldehyde/PBS at $4{ }^{\circ} \mathrm{C}$ for $2 \mathrm{~h}$. Subsequently, each sample was rinsed three times in PBS/4 $\mathrm{mM} \mathrm{MgCl}_{2}$ for $2 \mathrm{~h}$. Samples were then immersed in $\mathrm{X}-\mathrm{Gal}$ staining solution $(0.2 \% \mathrm{X}-\mathrm{Gal}, 2 \mathrm{mM}$ $\mathrm{MgCl}_{2}, 5 \mathrm{mM} \mathrm{K}_{4} \mathrm{Fe}(\mathrm{CN})_{6}, 5 \mathrm{mM} \mathrm{K}_{3} \mathrm{Fe}(\mathrm{CN})_{6}$ prepared in PBS) for up to $16 \mathrm{~h}$ at $37^{\circ} \mathrm{C}$. Following three times $30 \mathrm{~min}$ PBS rinses the skin sample was visualised en face using a Stemi 2000-C Stereomicroscope (Zeiss, Welwyn Garden City, UK) and a KL1500 electronic external light source (Schott UK Limited, Stafford, UK), prior to each sample being embedded in OCT medium and stored at $-80^{\circ} \mathrm{C}$.

2.7.3.2. Preparation of skin cryosections and HEE staining. Skin samples embedded in OCT blocks were sectioned using a Cryostat FSE (Thermo Scientific Shandon, UK). Skin sections $(10 \mu \mathrm{m})$ were collected onto Superfrost Plus microscope slides and observed with an Olympus BX50 microscope (Olympus, Middlesex, UK). Selected slides 
were subsequently stained using haematoxylin and eosin (H\&E) to visualise the skin architecture [21].

2.7.3.3. Intravital fluorescence imaging. Skin treated with pEGFP-N1 plasmid was incubated for $24 \mathrm{~h}$ at $37{ }^{\circ} \mathrm{C}$, rinsed in PBS and fixed in $4 \%$ paraformaldehyde/PBS at $4{ }^{\circ} \mathrm{C}$ for $24 \mathrm{~h}$. Skin samples were then rinsed in PBS and imaged intravitally using the Kodak FX-Pro imaging system (Bruker Corporation), with wavelengths set to $470 \mathrm{~nm}$ (excitation) and $535 \mathrm{~nm}$ (emission)

2.7.3.4. Fluorescence microscopy of skin sections. Following $24 \mathrm{~h}$ incubation, skin samples were rinsed in PBS and fixed in 4\% paraformaldehyde/PBS at $4{ }^{\circ} \mathrm{C}$ for $24 \mathrm{~h}$. Skin was then cryosectioned (Section 2.7.3.2) and imaged using the Leica DM IRB epifluorescence microscope and imaging system (Leica Microsystems Ltd., UK).

2.7.3.5. Preparation of epidermal sheets and fluorescent microscopy. Skin treated with pEGFP-N1 was incubated for $24 \mathrm{~h}$ at $37^{\circ} \mathrm{C}$ before epidermal sheets were isolated by heat separation. Skin biopsy punches were incubated in water at $60{ }^{\circ} \mathrm{C}$ for $55 \mathrm{~s}$ after which the epidermis was removed from the dermis using forceps under a dissection microscope. Isolated epidermal sheets were then washed in PBS, fixed in acetone for 20 min at $-20^{\circ} \mathrm{C}$, washed again and mounted on slides using Dako fluorescent mounting medium (Dako, UK). The tissue was then visualised by a Leica DMI6000B confocal microscope (Leica Microsystems (UK) Ltd., UK) with LAS AF software (Leica Microsystems (UK) Ltd., UK).

2.7.3.6. Fluorescence analysis of skin cells by flow cytometry. Excised skin was maintained in organ culture for $24 \mathrm{~h}$ prior to removal of the lower dermis by blunt dissection [55]. The remaining tissue was immersed in an enzyme solution containing Dispase II ( 2 units $/ \mathrm{mL}$ ) (Roche, UK), Collagenase I (197 units/mL) and Deoxyribonuclease I (DNA-se I) from bovine pancreas (20 units/mL) in RPMI 1640 (all Invitrogen, UK) for $1 \mathrm{~h}$ at $37^{\circ} \mathrm{C}$. Epidermal sheets were then mechanically separated from the dermis using forceps and placed in $0.25 \%$ $(\mathrm{w} / \mathrm{v})$ solution of trypsin for $30 \mathrm{~min}$ at $37^{\circ} \mathrm{C}$. Following incubation, the epidermal sheets were pipetted up and down to increase cell yield and the suspension of the cells was passed through a $70 \mu \mathrm{m}$ cell strainer. Single cell suspensions were subsequently centrifuged at $400 \times \mathrm{g}$ for $10 \mathrm{~min}$ and washed in PBS. Pelleted cells were fixed with $100 \mu \mathrm{L}$ of fixation buffer (BD Biosciences, UK) for $15 \mathrm{~min}$ at $4{ }^{\circ} \mathrm{C}$, washed and re-suspended in $200 \mu \mathrm{L}$ of stain buffer (BSA), (BD Biosciences, UK) before flow cytometry analysis (Section 2.5.5).

\subsection{Optical coherence tomography (OCT) of human skin following $M N$ delivery}

Excised human skin was removed from $-20{ }^{\circ} \mathrm{C}$ storage and allowed to equilibrate to room temperature for approximately $2 \mathrm{~h}$. Sub-cutaneous adipose tissue was removed by blunt dissection and skin was pinned, dermis side down, onto a cork dissection board to facilitate injection. Real time injections of methylene blue were visualised using the VivoSight System (Michelson Diagnostics, UK). The system is a Swept Source Fourier Domain OCT with clinical CE and FDA approval. This MultiBeam OCT system with $<7.5 \mu \mathrm{m}$ lateral resolution and $<5 \mu \mathrm{m}$ axial resolution in tissue is capable of achieving between 1.2 and $2.0 \mathrm{~mm}$ imaging depth and a $6 \times 6 \mathrm{~mm}$ lateral field of view. Each OCT scan consists of $60 \mathrm{~B}$-scans (in the $\mathrm{x}-\mathrm{y}$ plane) with $4 \mu \mathrm{m}$ pixels, separated by $100 \mu \mathrm{m}$ in the y direction.

\subsection{Data processing}

Image processing, including scale bar inclusion, was performed using ImageJ software (National Institute of Health, USA). Statistical analysis of transfection efficiency was determined by $t$-test analysis using GraphPad Prism software version 6.0c.

\section{Results}

\subsection{Characterisation of $M N$ devices}

Micronjet is a CE marked and FDA cleared device consisting of three MNs, each $600 \mu \mathrm{m}$ in length with a lumen that is approximately $60 \mu \mathrm{m}$ in diameter, bonded to a plastic adapter that permits attachment to a Luer fit syringe (Fig. 1).

\subsection{In vitro transfection of immortalised and primary keratinocytes}

Immortalised keratinocytes (HaCaT) were used to exemplify the functionality of the pEGFP-N1 and pIRES-TdTomato reporter plasmids. Freshly isolated human keratinocytes were subsequently used to determine transfection efficiency as these cells are more representative of the in vivo environment. A significant proportion $(44.1 \pm 0.2 \%)$ of $\mathrm{HaCaT}$ cells were positive for gene expression following treatment with the pEGFP-N1:Lipofectamine2000 lipoplex (Fig. 2A). The detection of gene expression was reduced $(10.1 \pm 0.4 \%)$ in cells transfected with pIRESTdTomato:Lipofectamine2000 (Fig. 2D). Gene expression efficiency in freshly isolated primary skin cells was reduced by an order of magnitude, with $3.8 \pm 0.4 \%$ of the cell population transfected by pEGFP-N1 lipoplexes, and $0.8 \pm 0.1 \%$ for pIRES-TdTomato lipoplexes. Positive transfection by GFP and TdTomato was confirmed by fluorescence micrographs of HaCaT cells (Fig. 2B and E) and primary keratinocytes (Fig. 2C and F).

\subsection{Evaluating MicronJet mediated delivery of plasmid DNA in human skin}

Experiments in viable human skin explants were performed to determine gene expression efficiency ex vivo following plasmid delivery via Micronjet MNs. Fig. 3 provides representative en face images of X-gal stained ex vivo human skin, $24 \mathrm{~h}$ after Micronjet delivery of the $\mathrm{pCMV} \beta$ reporter plasmid (Fig. 3B-D and F-H) or PBS as a control (Fig. 3A and E). Histological sections indicate that MN penetration of human skin typically creates disruptions in human skin to a depth of $200-250 \mu \mathrm{m}$ and a width of $150 \mu \mathrm{m}$ (Fig. 3A). Gene expression, visualised as areas of punctate intense blue staining, is extensive with multiple sites of reporter protein staining (Fig. 3B and C). Successful transfection was evident in at least three independent experiments in different skin donors and at all pCMV $\beta$ doses delivered $(22.5 \mu \mathrm{g}, 50 \mu \mathrm{g}$ and $250 \mu \mathrm{g})$. En face images and transverse sections (Fig. 3B, C, F and G) suggest that gene expression

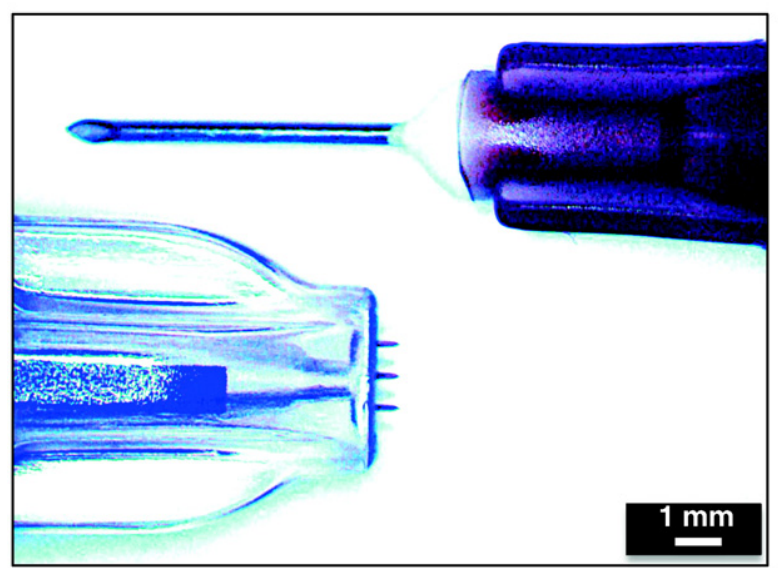

Fig. 1. A hypodermic needle with intradermal-bevel (26-gauge) and Nanopass Micronjet $600 \mu \mathrm{m}$ needles (brightfield microscopy). 

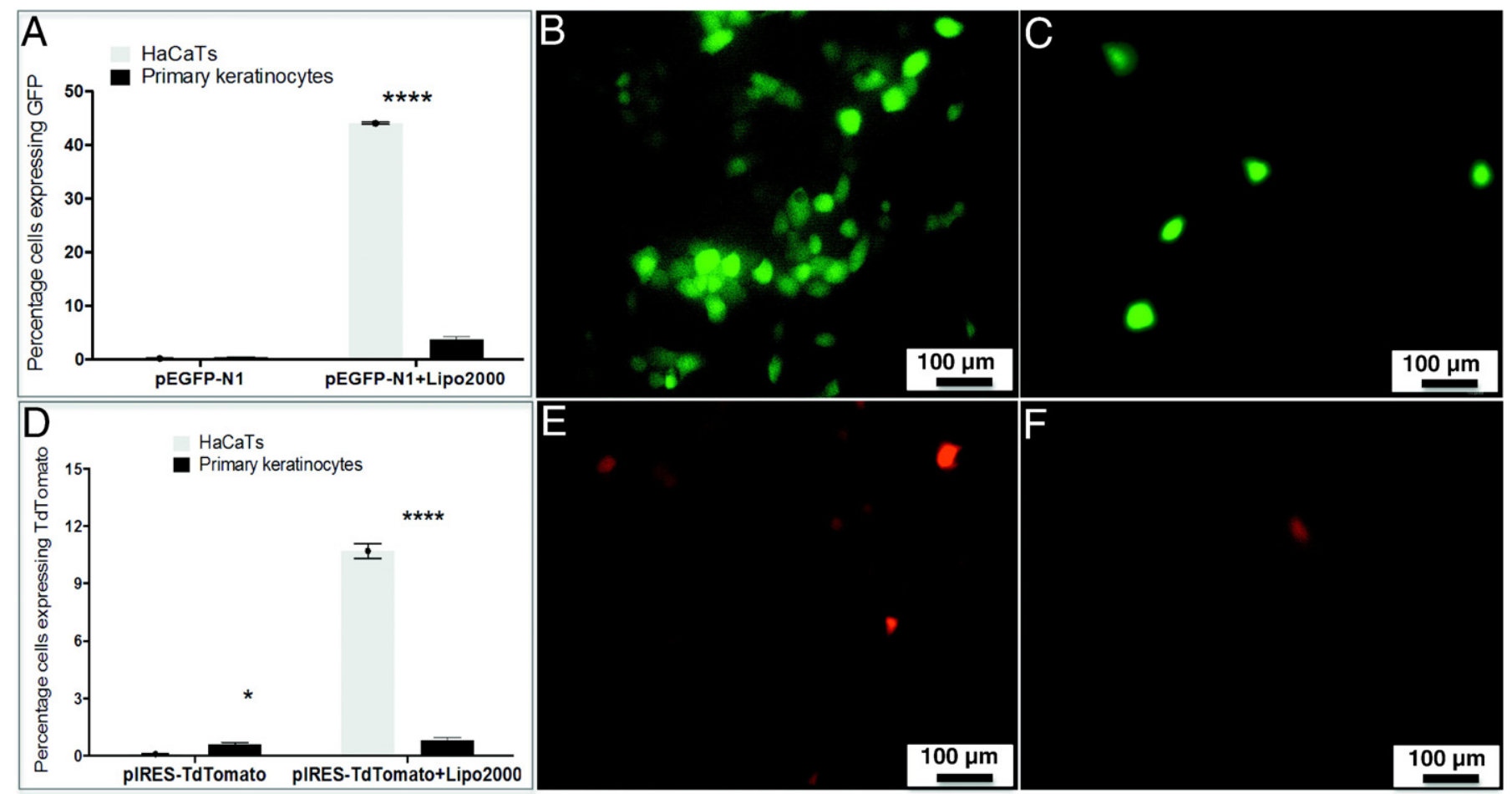

Fig. 2. Transfection efficiency of (A) pEGFP-N1 and (D) pIRES-TdTomato plasmids, as determined by flow cytometry of immortalised and primary human keratinocyte cell lines. Representative fluorescence micrographs of $\mathrm{HaCaT}(\mathrm{B}, \mathrm{E})$ and primary keratinocyte human cell lines (C, F) treated with pEGFP-N1 (B, C) and pIRES-TdTomato (E, F) lipoplexes with Lipofectamine2000 are also included to provide qualitative analysis. pDNA dose $0.6 \mu \mathrm{g}$ in each treatment group. Statistical analysis: ${ }^{*} \mathrm{p}<0.05$, ${ }^{* * * *} \mathrm{p}<0.0001$.

occurs predominantly in the viable epidermis although gene expression can also been observed in the dermis (Fig. 3D, G and H). It is interesting to note that the site of gene expression was remote from the injection site (Fig. 3B and C). Furthermore, whilst injection of naked plasmid DNA resulted in positive gene expression, injection of pCMV $\beta$ plasmid $(22.5 \mu \mathrm{g}$ ) complexed with Lipofectamine 2000 did not result in detectable gene expression in ex vivo human skin (data not shown).
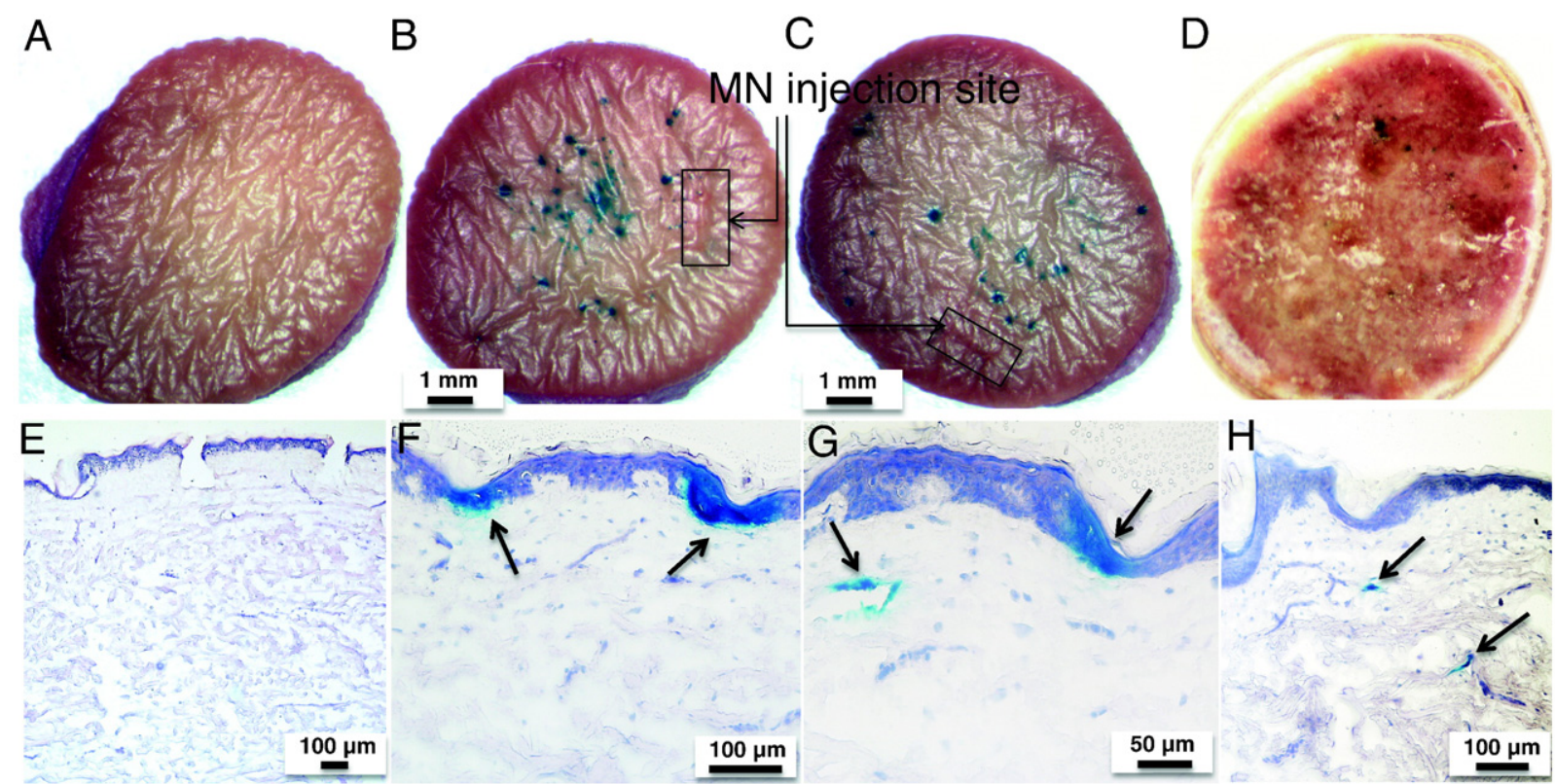

$\mathrm{H}$

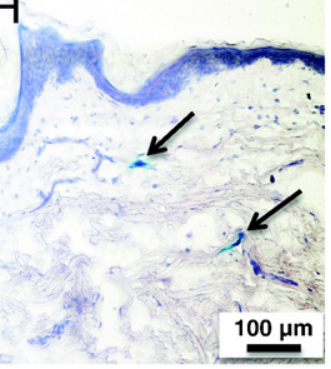

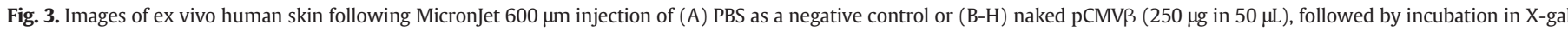

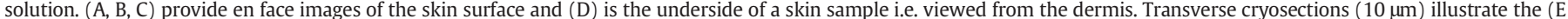

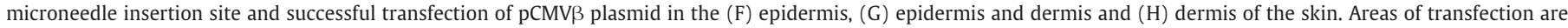
highlighted by arrows. Donor skin in these exemplar images was obtained from 71 (A-C, E-H) and 54 year old females. 
Intravital imaging of human skin explants $24 \mathrm{~h}$ after Micronjet injection of naked pEGFP-N1 plasmid (300 $\mu \mathrm{g}$ ) confirmed the results observed with $p C M V \beta$, with the expressed GFP causing a significant increase in the fluorescence intensity for all four treated skin samples compared to the negative control. The pattern of localised expression also supports previous observations with $\mathrm{pCMV} \beta$, i.e. there is evidence of increased fluorescence distant from the injection site but within the confines of the raised bleb that is produced upon Micronjet injection of $50 \mu \mathrm{L}$ of pDNA solution (Fig. 4B). Fluorescence imaging of epidermal sheets isolated from skin samples post-transfection validates the positive gene expression witnessed in intravital images (Fig. 4C and D), whilst traditional histology methods confirm that gene expression occurs predominantly within the viable epidermis (Fig. 4E and F).
In a further experiment ex vivo human skin was treated with pEGFPN1 delivered via MicronJet MNs 24 h prior to epidermal cells being extracted from the tissue and analysed by fluorescence activated cell sorting (FACS). FACS plots indicate that a small population of the extracted epidermal cells were GFP positive (Fig. 5B). Positive expression of the reporter protein in these skin-derived cells is further supported by fluorescence microscopy (Fig. 5D).

\subsection{Understanding MicronJet-mediated delivery of plasmid DNA at the cellular level}

To determine the influence of the delivery method on transfection, pEGFP-N1 was delivered to a HaCaT cell monolayer either using a variable volume pipette or using MicronJet MNs. Lipoplexes of pEGFP-N1 with Lipofectamine2000 (positive control) facilitated transfection of a

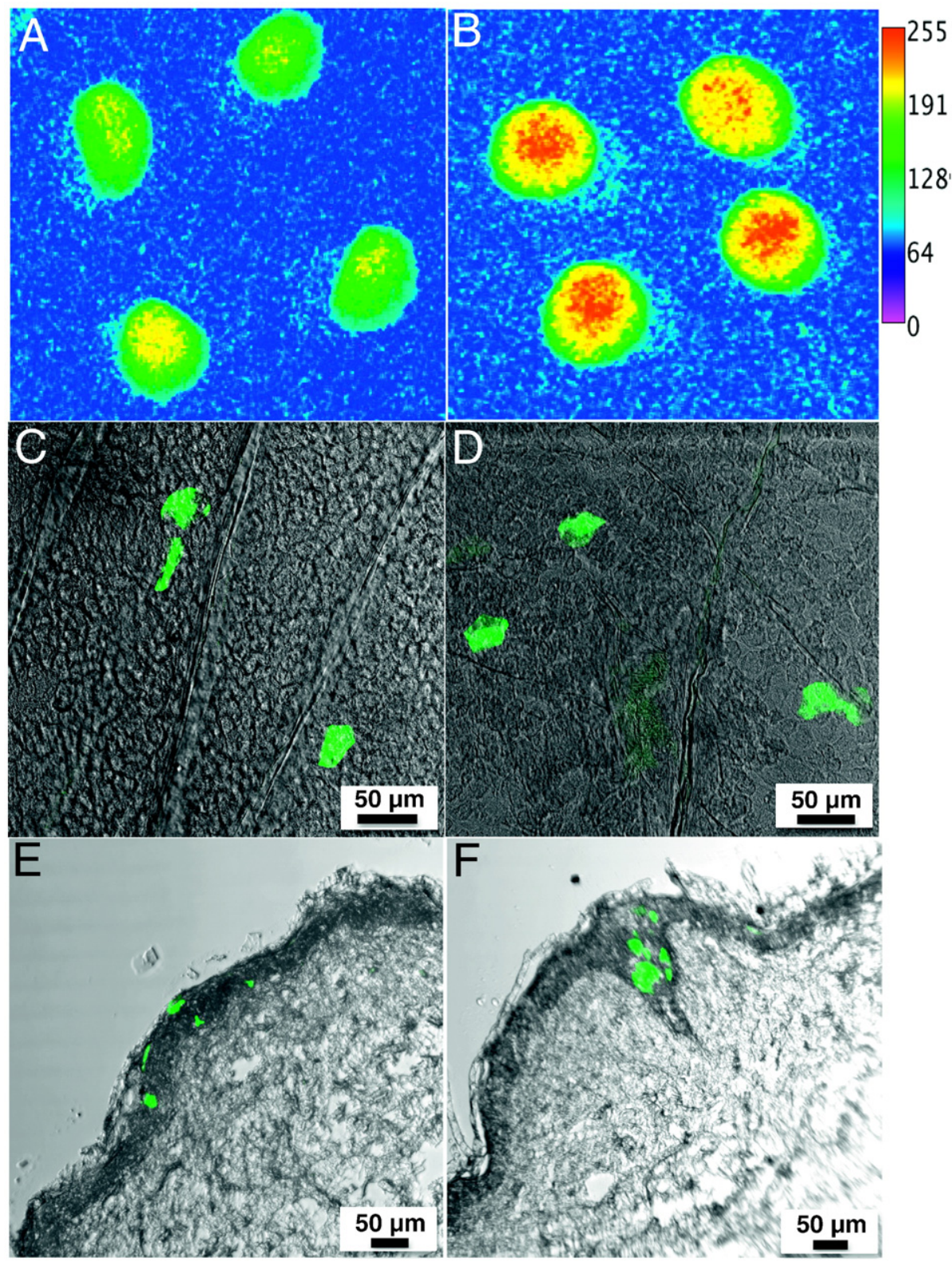

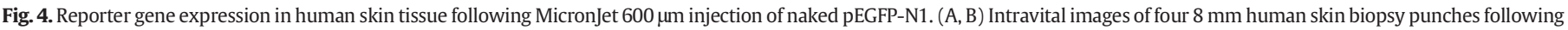

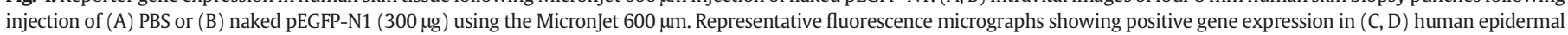

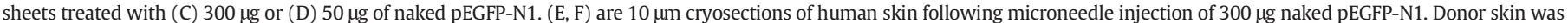
obtained from 75 (A-B, E-F) and 60 year old females. 

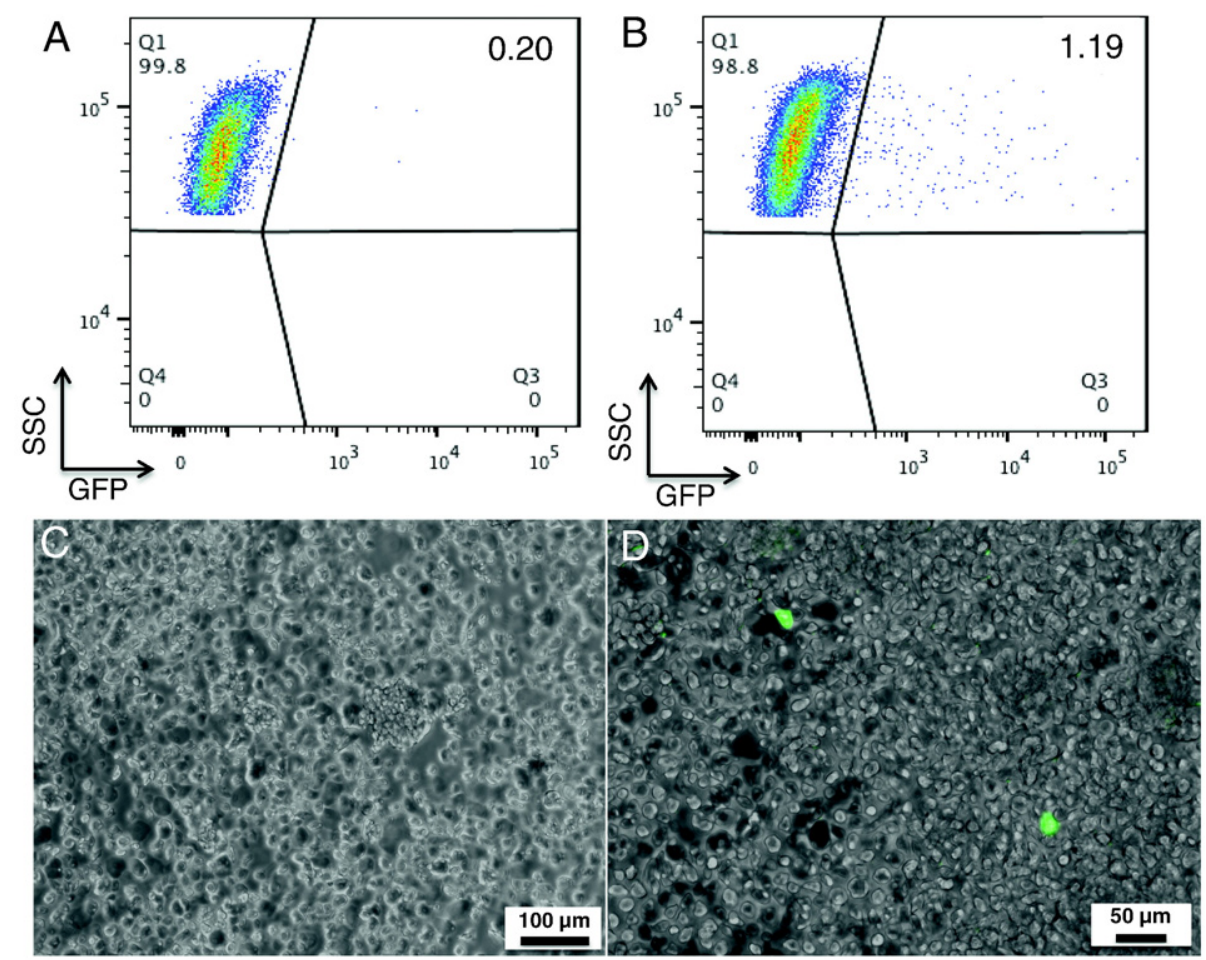

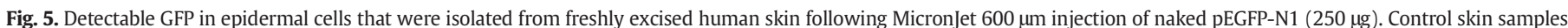

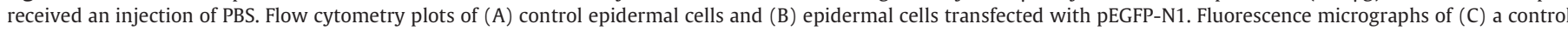

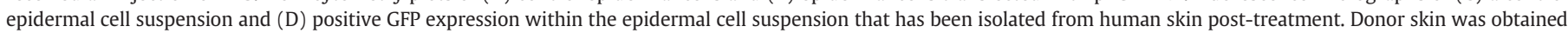
from a 67 year old female.

significant proportion of cells (Fig. 6B and D). Flow cytometry and fluorescence micrographs indicate that naked pEGFP-N1, delivered via Micronjet MNs (Fig. 6C and E), can successfully transfect a small proportion of cells in vitro. However, this low level of gene expression was not observed when naked pEGFP-N1 was applied to the cell monolayer using a pipette (Fig. 6A).
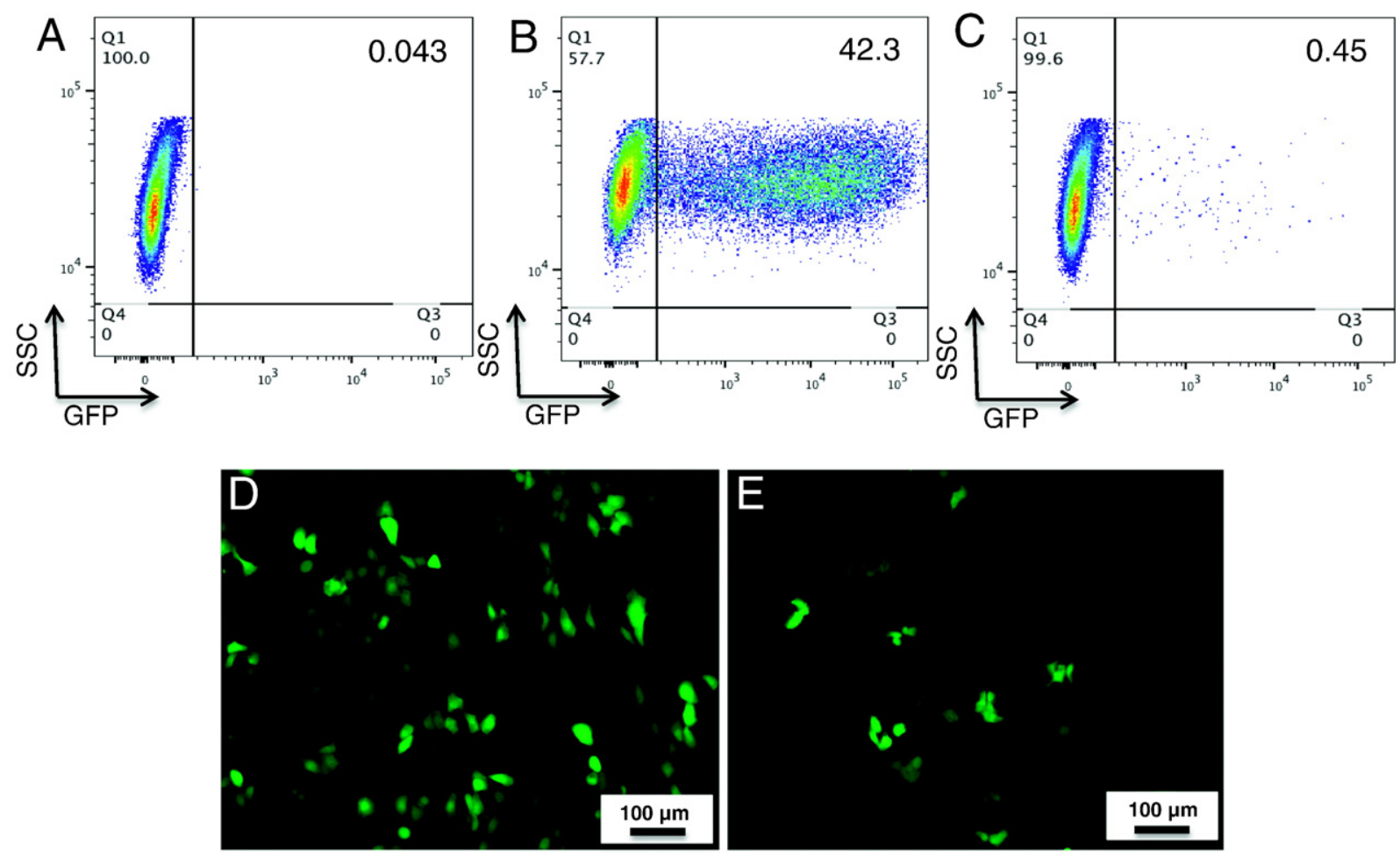

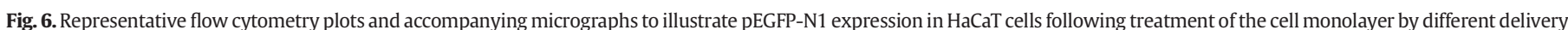

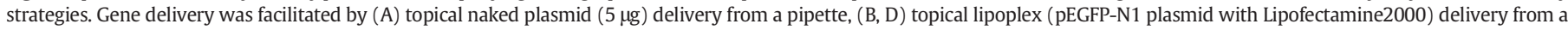
pipette (positive control) or (C, E) naked plasmid $(5 \mu \mathrm{g})$ extruded on to the cell monolayer through a Micronjet $600 \mu \mathrm{m}$. 
3.5. Understanding Micronjet mediated delivery of plasmid DNA at the tissue level

Optical coherence tomography (OCT) captured real time changes in the skin architecture during bleb formation by the MicronJet device. Localised disruption of the tissue at the point of injection was accompanied by adjacent distinct minor tissue disruptions, exclusive to the area of bleb formation (see Suppl. Fig. 1A-C and Fig. 7B and C). These microdisruptions appeared in a region of the tissue that is approximately $200-500 \mu \mathrm{m}$ below the skin surface and are a feature that were not witnessed in untreated skin (Fig. 7A) or during conventional intradermal injections (see Suppl. Fig. 1A). Subsequent histological examination of the tissue following injection of $\mathrm{pCMV} \beta$ supported OCT images, showing in some cases positive gene expression localised to areas of significant tissue disruption (Fig. 7D, E and F).

Conventional intradermal injection of $\mathrm{pCMV} \beta$ into ex vivo human skin resulted in gene expression in cells of the viable epidermis that are frequently adjacent to the point of injection (Fig. 8B and C). Histological evaluation of the skin indicated that transfection is either associated with the epidermal cells that are proximal to the point of needle
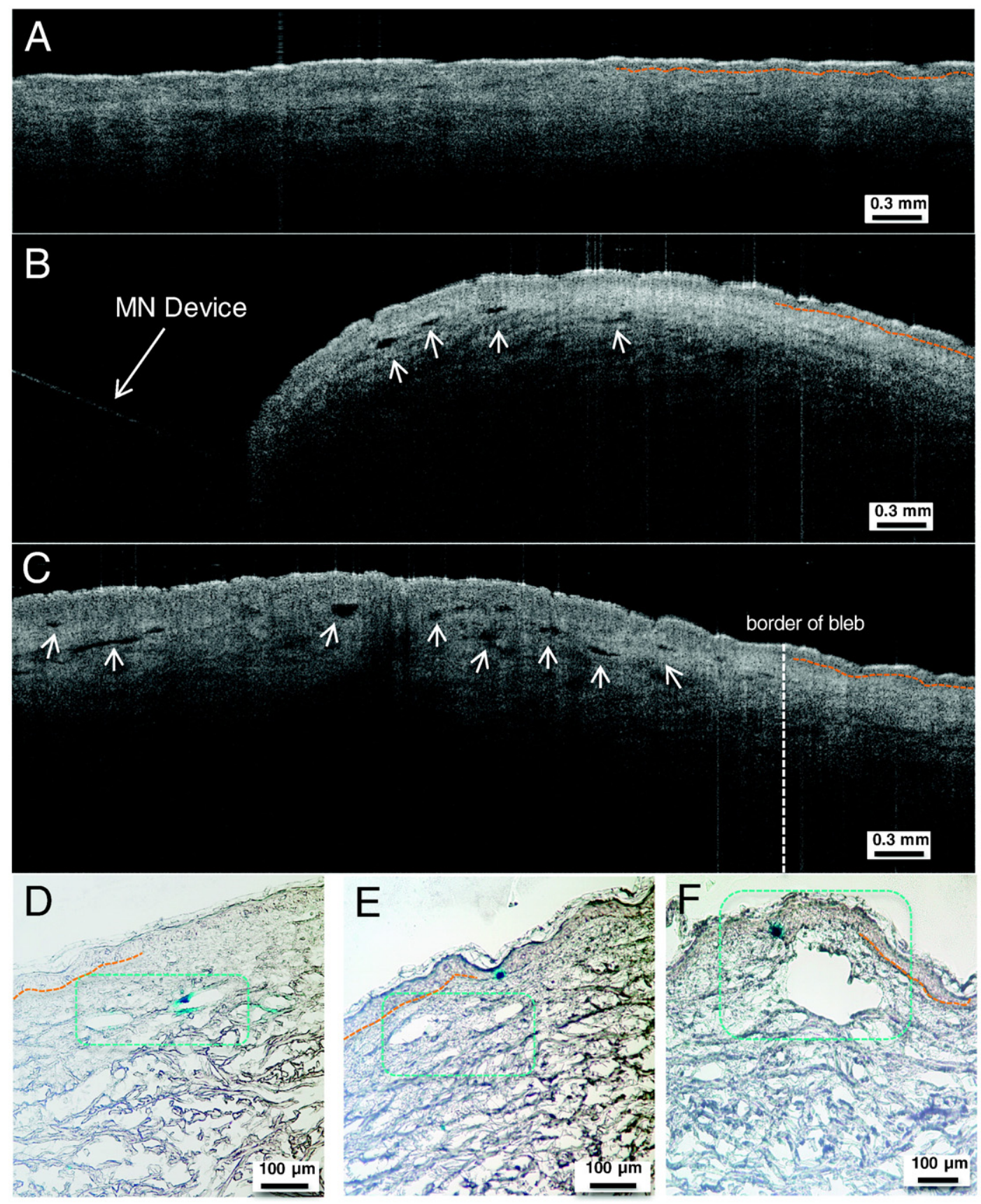

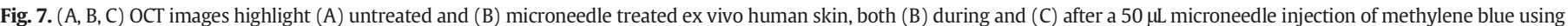

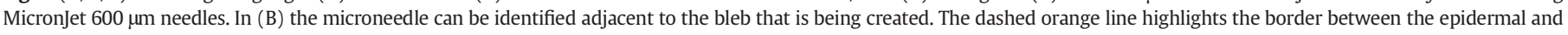

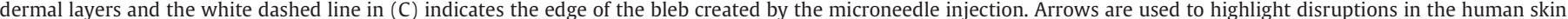

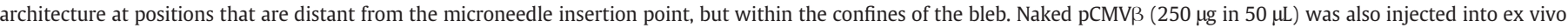

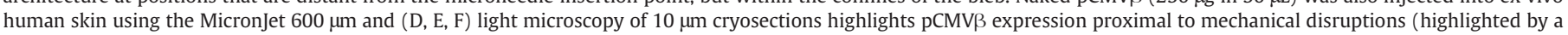
dashed blue line) in the skin tissue. Donor skin was obtained from 70 (A, B), 69 (C) and 71 (D, E, F) year old females. 

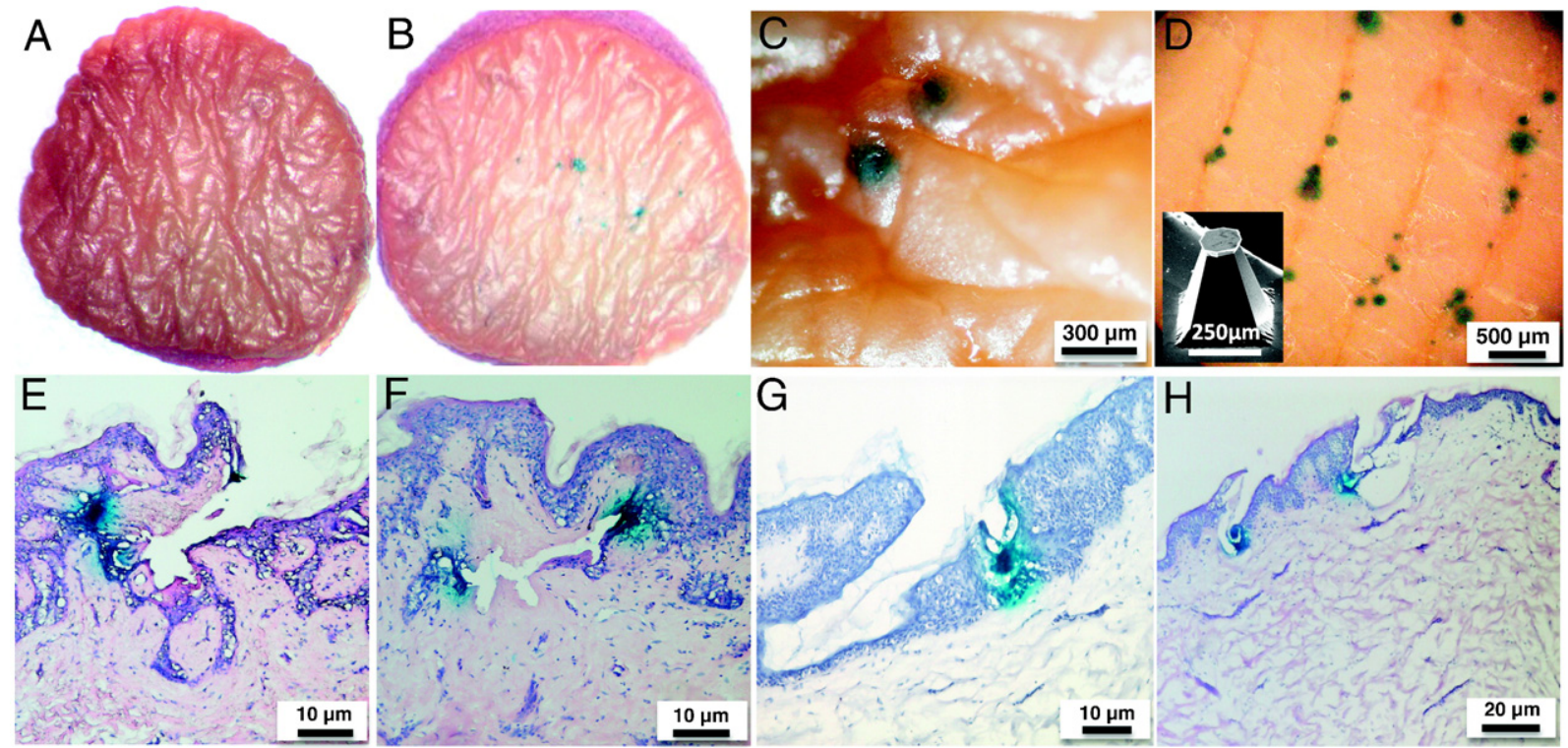

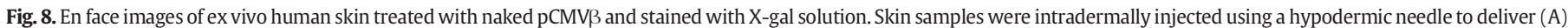

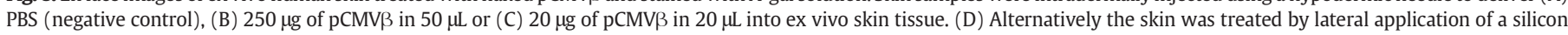

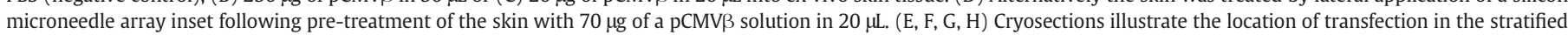

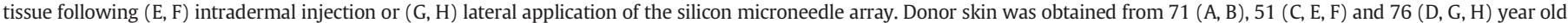
females.

entry into the skin (the needle track, Fig. 8E) or, if the tip of the needle was positioned in a cellular region, at the tip of the needle (both of these features were identified in a single sample in Fig. 8F). Transfection following conventional intradermal injection of commensurate volumes of $\mathrm{pCMV} \beta$ was therefore less extensive and significantly reduced compared to that observed with Micronjet injection.

To further explore the role of mechanical tissue disruption in mediating localised gene expression, silicon MN-like frustums were used to scarify the skin surface following topical liquid application of the $\mathrm{pCMV} \beta$ plasmid. Lateral movement of the frustums across the skin surface resulted in multiple discrete areas of gene expression proximal to the mechanical microdisruptions (Fig. 8D). Transverse sections confirmed plasmid expression in the viable epidermis and frustum induced mechanical microdisruptions in the upper layers of the tissue i.e. the epidermis and the papillary dermis (Fig. 8G and $\mathrm{H}$ ).

\section{Discussion}

There is a growing body of research that describes delivery of pDNA to murine $[22,24,37,39,66]$ and other animal $[14,83]$ models using solid MNs, particularly in the context of vaccination. Whilst these studies provide valuable information related to biological end-points and also exemplify the potential of solid MNs for pDNA delivery, the gross architecture and biology of animal and human skin have acknowledged differences, including the density, locations, proportions and phenotypes of both epidermal and dermal cells. Studies have also evaluated pDNA delivery in a viable ex vivo human skin model [55], but whilst studies have demonstrated proof-of-concept $[3,12,13,47,61,66]$, the "soak and poke" and "coat and poke" strategies are associated with limitations related to dosing reproducibility and transfection efficiency.

In this study hollow MNs (Fig. 1) were used, for the first time, for the minimally invasive delivery of a pDNA solution into human skin. Experiments using two different reporter plasmids indicate that following Micronjet delivery of a known bolus dose of pDNA into human skin, transfection is more extensive and reproducible (Figs. 3 \& 4) than that previously observed using the "soak and poke" $[3,12,60,83]$ or "coat and poke" MN approaches [14,22,24,36,61,66]. Most notably, the punctate areas of intense gene expression are remote from the injection site. This suggests that the Micronjet device facilitates transfection by a different mechanism than other published MN delivery strategies. A series of experiments were therefore conducted to elucidate the mechanism by which gene expression is enhanced upon MicronJet delivery of reporter pDNA to ex vivo human skin.

Initial studies used a well-characterised immortalised human keratinocyte cell line (HaCaT cells) to exemplify the functionality of the reporter pDNA. Cell delivery using a commercial non-viral transfection reagent produced transfection rates of over $40 \%$ (Fig. 2), however this did not translate to primary keratinocytes (Fig. 2). The nuclear envelope is the major intracellular barrier to nuclear delivery of pDNA [15] and therefore transfection efficiencies are greatest in rapidly dividing cells, where the nuclear envelope is briefly but repeatedly compromised during mitosis $[17,52,56,80]$. Primary cells proliferate slowly and therefore transfection efficiencies in these cells are reduced. In terminally differentiating primary keratinocytes, where nuclear entry relies on passive translocation via the nuclear pore complex $[46,67,82]$, this problem is exacerbated. Therefore whilst immortalised keratinocytes and non-viral vectors are useful laboratory tools, the more representative primary keratinocyte cells used in this study exemplify the cellular barriers to transfection that exist in vivo.

Treatment of the skin with a solid MN temporarily disrupts the stratum corneum and the plasma membranes of underlying viable cells. It has therefore been hypothesised that pre-treatment of the skin surface with a topical pDNA solution prior to application of a MN device ("soak and poke") can facilitate almost simultaneous passage of pDNA across the skin barrier and into the cytoplasm of the cells in the viable epidermis $[61,83]$. If the cell membrane recovers after this mechanical trauma, and cell viability is maintained, intracellular delivery of pDNA will translate to expression of the exogenous gene product. The drawback of this mechanism of delivery is the exclusive proximity of positively-expressing cells to the MN insertions, which necessitates extensive or repeated $\mathrm{MN}$ applications to facilitate reasonable levels of gene expression. "Coat and poke" [61] and "poke and soak" [11,49,60,83] strategies produce lower levels of gene expression due to the time delay between MN induced disruption of the cell membranes and exposure of the compromised cells to the pDNA. This delay is dependent on either the dissolution rate of the relatively insoluble macromolecular nucleic acid within the local environment of the skin tissue ("coat and poke") or the interval between treatment of the skin with the MN device and 
topical application of a pDNA solution ("poke and soak"). Therefore the significant enhancement in both the level and distribution of gene expression following the use of hollow MNs, compared to their solid counterparts, suggests that hollow MNs can improve cellular delivery as well as providing more reproducible and controlled dosing into the tissue.

Delivery of a liquid bolus into human skin using a hollow MN is more comparable to a conventional intradermal injection than delivery using solid MNs. However, the level and location of gene expression observed in ex vivo human skin following delivery of pDNA by hollow MNs is also significantly greater than that achieved using conventional intradermal injection (Fig. 8B). Conventional intradermal injections use a $260 \mu \mathrm{m}$ needle bore and expel the liquid bolus in a single stream, compared to Micronjet, which uses three $60 \mu \mathrm{m}$ bores. The smaller bore sizes of the Micronjet increase the exit velocity of the liquid when a comparable downward pressure is applied to the syringe. The increased velocity is likely to facilitate greater direct cell transfection. In vitro experiments partially exemplified this point (Fig. 6), with increased transfection evident when the naked pDNA was applied to cell monolayers using the Micronjet device compared to a pipette tip, although absolute gene expression levels remain low. Direct cell transfection by a high velocity liquid is also supported by a significant body of literature related to jet injections $[10,18-20,65,74,75]$. However, although a jet injection mechanism may contribute to the heightened gene expression observed in this study, the limited number of jets and the extensive distribution of gene expression suggest that it is unlikely to be the sole or major reason for the enhancement.

pDNA delivery using hollow MNs results in gene expression in cells remote from the point of injection, but which are restricted to the 'bleb' that is created by the intradermal liquid bolus (Figs. 3 \& 4). This 'bleb', as it is commonly referred to, is a discrete area of skin tissue that temporarily expands in response to the intradermal administration of a liquid volume. This type of event is also witnessed during the hydrodynamic delivery of nucleic acids to animal models $[5,44,68,86]$, where a high speed and large volume tail vein injection of pDNA causes the liver to more than double in size [69]. Delivery of a large volume of liquid into the confined tissue space of the liver results in hydrostatic pressures that create temporary pores in the plasma membranes of cells, thus increasing permeability and heightening transfection. In animal models this facilitates gene expression in large numbers of cells in the liver and detectable levels of gene expression in other internal organs. This technique has also been transferred to animal skin, where rapid intradermal injection of a large volume (up to $100 \mu \mathrm{L}$ ) of pDNA solution into a mouse foot pad facilitates significant gene expression [23]. González-González et al. suggest that the presence of nucleic acid in the epidermis is not enough to facilitate keratinocyte uptake and propose that the hydrodynamic pressure created by intradermal injection of a relatively large volume of liquid into the confined space of the mouse foot pad causes transient membrane disruption of skin cells and facilitates cell uptake and subsequent plasmid expression. To date, there have been no published studies that have used hydrodynamic delivery to facilitate transfection in human skin.

In human skin conventional intradermal injection of a pDNA solution results in observable expansion of the skin tissue. However there is limited gene expression and this is restricted to the point of injection and/or the needle track (Fig. 8A-C; E-F). The extent and pattern of transfection following conventional injection is therefore not characteristic of hydrodynamic delivery and is more likely caused by direct jet injection at the needle orifice and/or temporary mechanical damage to the cells at the point of needle insertion. The pressure created in the human tissue by conventional intradermal injection of $50 \mu \mathrm{L}$ of a pDNA solution is therefore not great enough to facilitate extensive transfection in the cellular region of the skin. However delivery of the same injection volume $(50 \mu \mathrm{L})$ containing the same reporter plasmid ( $\mathrm{pCMVB}$ ) to the same human skin model using the hollow MN device results in a significant enhancement to the level of exogenous gene expression (Fig. 3). It is therefore the specific delivery system i.e. the hollow MN, that is responsible for the increase in gene expression witnessed in this study.

Real time OCT videos and supportive microscopy images (Fig. 7 \& Suppl. Fig. $1 \mathrm{~A}-\mathrm{C}$ ) indicate that hollow MN delivery of the liquid bolus is more superficial than that of conventional intradermal injection and this results in multiple microdisruptions to the skin architecture in the papillary dermis and at the epidermal-dermal junction (Fig. 7 and Suppl. Fig. $1 \mathrm{~A}-\mathrm{C})$. These disruptions are created during the MN injection process (Fig. 7B and Suppl. Fig. 1B) but remain following completion of bolus delivery (Fig. 7C and Suppl. Fig. 1C). The disruptions were located at numerous points that are distant from the point of MN injection but within the confines of the bleb. Some of these changes were also colocalised with points of transfection (Fig. 7D). These disruptions were not observed upon conventional intradermal injections (Fig. 7A and Suppl. Fig. 1A). We therefore postulate that, unlike conventional intradermal injections, hollow MNs are able to force large volumes of liquid (relative to the skin volume) at high speed (typically less than few seconds to administer $50 \mu \mathrm{L}$ ) into the papillary dermis, where elastin and collagen fibres are tightly packed and are in direct contact with the viable cells of the epidermal basement membrane. This creates hydrostatic pressures that physically disrupt the local tissue architecture and cause a transient increase in the permeability of cells in this region, which results in notable gene expression located exclusively with the skin 'bleb' (Figs. 3 \& 4). This proposed mechanism of transfection is akin to the hydrodynamic delivery witnessed in animal models, the main difference being that we have used a hollow MN device to replicate this in human skin tissue and have achieved it using relatively low injection volumes $(50 \mu \mathrm{L})$.

The pattern of gene expression following hollow MN mediated delivery of pDNA was not uniform. Discrete areas of gene expression were observed, predominantly in the viable epidermis but also in the dermis (Figs. 3-5). The disparate pattern of gene expression is unsurprising given the proposed mechanism of transfection, i.e. hydrodynamic delivery is unlikely to create a uniform pattern of disruption in a heterogeneous tissue architecture. Indeed, OCT images and histology (Fig. 7) support this, highlighting discrete areas of mechanical tissue disruption in the papillary dermis and epidermis, rather than uniform tissue disruption. Lateral application of a MN device [49] to the human skin model was used as an alternative method to create extensive superficial physical disruptions in the viable epidermis and papillary dermis (Fig. 8D, G-H). Delivery using this method also produced a random pattern of discrete areas of gene expression proximal to those points of mechanical disruption. Whilst lateral microneedle application is not clinically useful, as it causes significant mechanical damage to the stratum corneum barrier, it provides an interesting comparator and supports the hypothesis that intradermal delivery of a pDNA solution through the Micronjet system can physically disrupt cell membranes in the papillary dermis and viable epidermis by a hydrodynamic effect In the case of hollow MNs, it does this without compromising the protective stratum corneum barrier.

Transfection levels in the excised human tissue are therefore considerable following pDNA delivery by the Micronjet. However, when skin cells are subsequently extracted from the bleb the relative number of transfected cells in the tissue is low (Fig. 5). This is likely a compound factor of the inherent difficulty in transfecting the dominant cell type of the epidermis i.e. primary terminally differentiating cells (Fig. 2), restricted access of pDNA to all cells within the three dimensional skin architecture and, potentially, damage to transfected cells during extraction from the tissue. Successful transfection also relies on transient disruption of the plasma membrane, but in a proportion of cells the physical disruption is likely to be permanent and thus cause cell death. Therefore whilst the data provides an insight into the numbers of cells transfected it is likely to be an under-estimate of the transfection efficiency i.e. the number of cells expressing the exogenous gene as a proportion of those cells that are able to be transfected. The levels of localised gene expression demonstrated in this study may therefore 
be suitable when very high transfection efficiencies are not required e.g. nucleic acid vaccines or immunotherapy approaches.

The observed enhancement in performance, compared to conventional intradermal injection and solid MNs, encourages development of hollow MN delivery systems for nucleic acid therapies. Whilst electroporation is now being investigated as an adjunct to enhance intracellular delivery of pDNA following the application of solid MNs [78], the hydrodynamic mechanism of cellular delivery associated with use of the hollow MN device may provide a simpler alternative. To the best of our knowledge, this is the first time that hydrodynamic gene delivery has been achieved in human skin and therefore further work is now required to optimise delivery and translate these results from reporter genes to therapeutically relevant pDNA. The extent and reproducibility of exogenous gene expression in human skin indicates that the CE marked Micronjet device may therefore provide a valuable platform for nucleic acid vaccination strategies or immunotherapy approaches. It is also important to note that whilst multiple sub-surface microdisruptions created by the MicronJet in the skin are able to facilitate cellular uptake and subsequent expression of pDNA, there have been thousands of Micronjet injections with no reports of associated infection and therefore the enhancement in transfection is not at the expense of the minimally invasive principles of the MN delivery system.

\section{Conclusions}

This study exemplifies, for the first time, the use of hollow MNs for efficient vectorless delivery and expression of pDNA in human skin and proposes hydrodynamic delivery as the mechanism for enhanced gene expression, even with a 'standard' injection volume. Hydrodynamic gene delivery has not previously been observed in human skin tissue. The approved Micronjet hollow MN system ensures accurate delivery of a finite dose of exogenous DNA into the skin and provides more efficient and reproducible gene expression compared to solid MN delivery strategies. The delivery method provides potential advantages over other chemical and physical gene delivery methods with respect to cost, simplicity and flexibility of dosing and therefore could be the basis for future nucleic acid based immunotherapies and vaccines.

Supplementary data to this article can be found online at http://dx. doi.org/10.1016/j.jconrel.2017.02.028.

\section{Acknowledgements}

This work is part of the EE-ASI European research network (Collaborative Project) supported by the European Commission under the Health Cooperation Work Programme of the 7th Framework Programme (grant agreement no. 305305).

\section{References}

[1] A. Abdul-Wahab, W. Qasim, J.A. McGrath, Gene therapies for inherited skin disorders, Semin. Cutan. Med. Surg. 33 (2) (2014) 83-90.

[2] A.D. Bins, A. Jorritsma, M.C. Wolkers, C.F. Hung, T.C. Wu, T.N. Schumacher, J.B. Haaneen, A rapid and potent DNA vaccination strategy defined by in vivo monitoring of antigen expression, Nat. Med. 11 (2005) 899-904.

[3] J.C. Birchall, S.A. Coulman, M. Pearton, C. Allender, K. Brain, A. Anstey, C. Gateley, N. Wilke, A. Morrissey, Cutaneous DNA delivery and gene expression in ex vivo human skin explants via wet-etch microfabricated microneedles, J. Drug Target. 13 (7) (2005) 415-442.

[4] J.C. Birchall, S.A. Coulman, A. Anstey, C. Gateley, H. Sweetland, A. Gershonowitz, L. Neville, G. Levin, Cutaneous gene expression of plasmid DNA in excised human skin following delivery via microchannels created by radio frequency ablation, Int. J. Pharm. 312 (1-2) (2006) 15-23.

[5] B. Bonamassa, L. Hai, D. Liu, Hydrodynamic gene delivery and its applications in pharmaceutical research, Pharm. Res. 28 (4) (2011) 694-701.

[6] P. Boukamp, R.T. Petrussevska, D. Breitkreutz, J. Hornung, A. Markham, N.E. Fusenig, Normal keratinization in a spontaneously immortalized aneuploid human keratinocyte cell line, J. Cell Biol. 106 (1988) 761-771.
[7] H. Boulaiz, J.A. Marchal, J. Prados, C. Melguizo, A. Aránega, Non-viral and viral vectors for gene therapy, Cell Mol. Biol. (Noisy-le-grand) 2 (51) (2005) 3-22.

[8] R.M. Brand, P.L. Iversen, Iontophoretic delivery of atelomeric oligonucleotide, Pharm. Res. 13 (1996) 851-854.

[9] K.E. Broderick, X. Shen, J. Soderholm, F. Lin, J. McCoy, A.S. Khan, J. Yan, M.P. Morrow A. Patel, G.P. Kobinger, S. Kemmerrer, D.B. Weiner, N.Y. Sardesai, Prototype development and preclinical immunogenicity analysis of a novel minimally invasive electroporation device, Mol. Ther. 3 (2011) 249-255.

[10] R. Cartier, S.V. Ren, W. Walther, U. Stein, A. Lewis, P.M. Schlag, M. Li, P.A. Furth, In vivo gene transfer by low-volume jet injection, Anal. Biochem. 282 (2000) 262-265

[11] F. Chabri, K. Bouris, T. Jones, D. Barrow, A. Hanna, C. Allender, K. Brain, J. Birchall, Microfabricated silicon microneedles for nonviral cutaneous gene delivery, $\mathrm{Br}$. J. Dermatol. 150 (5) (2004) 869-877.

[12] S.A. Coulman, D. Barrow, A. Anstey, C. Gateley, A. Morrissey, N. Wilke, C. Allender, K. Brain, J.C. Birchall, Minimally invasive cutaneous delivery of macromolecules and plasmid DNA via microneedles, Curr. Drug Deliv. 3 (1) (2006) 65-75.

[13] L. Daugimont, N. Baron, G. Vandermeulen, N. Pavselj, D. Miklavcic, M.-C. Jullien, G. Cabodevila, L.M. Mir, V. Preat, Hollow microneedle arrays for intradermal drug delivery and DNA electroporation, J. Membr. Biol. 236 (2010) 117-125.

[14] P.C. DeMuth, Y. Min, B. Huang, J.A. Kramer, A.D. Miller, D.H. Barouch, P.T. Hammond, D.J. Irvine, Polymer multilayer tattooing for enhanced DNA vaccination, Nat. Mater. 12 (4) (2013) 367-376.

[15] D.A. Dean, D.D. Strong, W.E. Zimmer, Nuclear entry of nonviral vectors, Gene Ther. 12 (11) (2005) 881-890.

[16] J.J. Drabick, J. Glasspool-Malone, A. King, R.W. Malone, Cutaneous transfection and immune responses to intradermal nucleic acid vaccination are significantly enhanced by in vivo electropermeabilization, Mol. Ther. 3 (2001) 249-255.

[17] V. Escriou, M. Carrière, F. Bussone, P. Wils, D. Scherman, Critical assessment of the nuclear import of plasmid during cationic lipid-mediated gene transfer, J. Gene Med. 3 (2) (2001) 179-187.

[18] A.S. Fargnoli, M.G. Katz, R.D. Williams, K.B. Margulies, C.R. Bridges, A needleless liquid jet injection delivery method for cardiac gene therapy: a comparative evaluation versus standard routes of delivery reveals enhanced therapeutic retention and cardiac specific gene expression, J. Cardiovasc. Transl. Res. 7 (8) (2014) 756-767.

[19] A.S. Fargnoli, M.G. Katz, R.D. Williams, A.P. Kendle, N. Steuerwald, C.R. Bridges, Liquid jet delivery method featuring S100A1 gene therapy in the rodent model following acute myocardial infarction, Gene Ther. 23 (2016) 151-157.

[20] P.A. Furth, A. Shamay, L. Henninghausen, Gene transfer into mammalian cells by jet injection, Hybridoma 14 (1995) 149-152.

[21] A.H. Fischer, K.A. Jacobson, J. Rose, R. Zeller, Haematoxylin and eosin staining of tissue and cell sections, CSH Protoc. (2008) (pdb.prot4986).

[22] H.S. Gill, J. Soderholm, M.R. Prausnitz, M. Sallberg, Cutaneous vaccination using microneedles coated with hepatitis C DNA vaccine, Gene Ther. 17 (6) (2010) 811-814.

[23] E. González-González, H. Ra, R. Spitler, P. Hickerson, C.H. Contag, R.L. Kaspar Increased interstitial pressure improves nucleic acid delivery to skin enabling a comparative analysis of constitutive promoters, Gene Ther. 17 (2010) 1270-1278.

[24] E. González-González, Y.C. Kim, T.J. Speaker, R.P. Hickerson, R. Spitler, J.C. Birchall, M.F. Lara, R.H. Hu, Y. Liang, N. Kirkiles-Smith, M.R. Prausnitz, L.M. Milstone, C.H. Contag, R.L. Kaspar, Visualization of plasmid delivery to keratinocytes in mouse and human epidermis, Sci. Rep. 1 (2011) 158.

[25] S. Guo, A. Donate, G. Basu, C. Lundberg, L. Heller, R. Heller, Electro-gene transfer to skin using a noninvasive multielectrode array, J. Control. Release 151 (2011) 256-262.

[26] J. Gupta, E.I. Felner, M.R. Prausnitz, Minimally invasive insulin delivery in subjects with type 1 diabetes using hollow microneedles, Diabetes Technol. Ther. 11 (6) (2009) 329-337.

[27] J. Gupta, D.D. Denson, E.I. Felner, M.R. Prausnitz, Rapid local anesthesia in humans using minimally invasive MNs, Clin. J. Pain 28 (2) (2012) 129-135.

[28] I.R. Hart, R.G. Vile, Targeted therapy for malignant melanoma, Curr. Opin. Oncol. 6 (1994) 221-225.

[29] C.H. He, Y. Tabata, J.Q. Gao, Non-viral gene delivery carrier and its three-dimensional transfection system, Int. J. Pharm. 386 (2010) 232-242.

[30] U.R. Hengge, E.F. Chan, R.A. Foster, P.S. Walker, J.C. Vogel, Cytokine gene expression in epidermis with biological effects following injection of naked DNA, Nat. Genet. 10 (1995) 161-166.

[31] U.R. Hengge, P.S. Walker, J.C. Vogel, Expression of naked DNA in human, pig, and mouse skin, J. Clin. Invest. 97 (1996) 2911-2916.

[32] U.R. Hengge, W. Pfützner, M. Williams, M. Goos, J.C. Vogel, Efficient expression of naked plasmid DNA in mucosal epithelium: prospective for the treatment of skin lesions, J. Invest. Dermatol. 111 (1998) 605-608.

[33] J.L. Howarth, Y.B. Lee, J.B. Uney, Using viral vectors as gene transfer tools (Cell Biology and Toxicology Special Issue: ETCS-UK 1 day meeting on genetic manipulation of cells), Cell Biol. Toxicol. 26 (1) (2010) 1-20.

[34] D. Ibraheem, A. Elaissari, H. Fessi, Gene therapy and DNA delivery systems, Int. J. Pharm. 459 (2014) 70-83.

[35] Y.C. Kim, M. Prausnitz, Enabling skin vaccination using new delivery technologies, Drug Deliv. Transl. Res. 1 (2011) 7-12.

[36] Y.C. Kim, D.G. Yoo, R.W. Compans, S.M. Kang, M.R. Prausnitz, Cross-protection by coimmunization with influenza hemagglutinin DNA and inactivated virus vaccine using coated microneedles, J. Control. Release 172 (2) (2013) 579-588.

[37] N.W. Kim, M.S. Lee, K.R. Kim, J.E. Lee, K. Lee, J.S. Park, Y. Matsumoto, D.G. Jo, H. Lee D.S. Lee, J.H. Jeong, Polyplex-releasing microneedles for enhanced cutaneous delivery of DNA vaccine, J. Control. Release 10 (179) (2014) 11-17. 
[38] T.M. Klein, E.D. Wolf, R. Wu, J.C. Sanford, High-velocity microprojectiles for delivering nucleic acids into living cells, Nature 327 (1987) 70-73.

[39] A. Kumar, P. Wonganan, M.A. Sandoval, X. Li, S. Zhu, Z. Cui, Microneedle-mediated transcutaneous immunization with plasmid DNA coated on cationic PLGA nanoparticles, J. Control. Release 163 (2) (Oct 28 2012) 230-239.

[40] M.A. Kutzler, D.B. Weiner, DNA vaccines: ready for prime time? Nat. Rev. Genet. 9 (2008) 776-788.

[41] Y. Levin, E. Kochba, R. Kenney, Clinical evaluation of a novel microneedle device for intradermal delivery of an influenza vaccine: are all delivery methods the same? Vaccine 32 (34) (2014) 4249-4252.

[42] Y. Levin, E. Kochba, I. Hung, R. Kenney, Intradermal vaccination using the nove microneedle device MicronJet600: past, present, and future, Hum. Vaccin. Immunother. 11 (4) (2015) 991-997.

[43] S. Li, L. Huang, Nonviral gene therapy: promises and challenges, Gene Ther. 7 (1) (2000) 31-34.

[44] F. Liu, Y. Song, D. Liu, Hydrodynamics-based transfection in animals by systemic administration of plasmid DNA, Gene Ther. 6 (1999) 1258-1266.

[45] H. Lv, S. Zhang, B. Wang, S. Cui, J. Yan, Toxicity of cationic lipids and cationic polymers in gene delivery, J. Control. Release 114 (1) (2006) 100-109.

[46] I.W. Mattaj, L. Englmeier, Nucleocytoplasmic transport: the soluble phase, Annu. Rev. Biochem. 67 (1998) 265-306.

[47] J. McCaffrey, R.F. Donnelly, H.O. McCarthy, Microneedles: an innovative platform for gene delivery, Drug Deliv. Transl. Res. 5 (4) (2015) 424-437.

[48] J.M. Meacham, K. Durvasula, F.L. Degertekin, A.G. Fedorov, Physical methods for intracellular delivery: practical aspects from laboratory use to industrial-scale processing, J. Lab Autom. 19 (1) (2014) 1-18.

[49] J.A. Mikszta, J.B. Alarcon, J.M. Brittingham, D.E. Sutter, R.J. Pettis, N.G. Harvey, Improved genetic immunization via micromechanical disruption of skin-barrier function and targeted epidermal delivery, Nat. Med. 8 (4) (2002) 415-419.

[50] M.A. Miller, E. Pisani, The cost of unsafe injections, Bull. World Health Organ. 77 (10) (1999) 808-811.

[51] F. Mingozzi, K.A. High, Immune responses to AAV vectors: overcoming barriers to successful gene therapy, Blood 122 (1) (2013) 23-36.

[52] I. Mortimer, P. Tam, I. MacLachlan, R.W. Graham, E.G. Saravolac, P.B. Joshia, Cationic lipid-mediated transfection of cells in culture requires mitotic activity, Gene Ther. 6 (3) (1999) 403-411.

[53] N. Nayerossadat, T. Maedeh, P.A. Ali, Viral and nonviral delivery systems for gene delivery, Adv. Biomed. Res. 1 (2012) 27.

[54] C.M.H. Newman, T. Bettinger, Gene therapy progress and prospects: ultrasound for gene transfer, Gene Ther. 14 (6) (2007) 465-475.

[55] K.W. Ng, M. Pearton, S. Coulman, A. Anstey, Ch. Gateley, A. Morrissey, Ch. Allender, J. Birchall, Development of an ex vivo human skin model for intradermal vaccination: tissue viability and Langerhans cell behavior, Vaccine 27 (43) (2009) 5948-5955.

[56] C. Nicolau, C. Sene, Liposome-mediated DNA transfer in eukaryotic cells. Dependence of the transfer efficiency upon the type of liposomes used and the host cell cycle stage, Biochim. Biophys. Acta 721 (2) (1982) 185-190.

[57] J.J. Norman, S.-O. Choi, N.T. Tong, A.R. Aiyar, S.R. Patel, M.R. Prausnitz, M.G. Allen, Hollow MNs for intradermal injection fabricated by sacrificial micromolding and selective electrodeposition, Biomed. Microdevices 15 (2) (2013) 203-210.

[58] C. O'Mahony, Structural characterization and in-vivo reliability evaluation of silicon microneedles, Biomed. Microdevices 16 (3) (2014) 333-343.

[59] K. Oosterhuis, J.H. van den Berg, T.N. Schumacher, J.B. Haanen, DNA vaccines and intradermal vaccination by DNA tattooing, Curr. Top. Microbiol. Immunol. 351 (2012) 221-250.

[60] M. Pearton, C. Allender, K. Brain, A. Anstey, C. Gateley, N. Wilke, A. Morrissey, J Birchall, Gene delivery to the epidermal cells of human skin explants using microfabricated microneedles and hydrogel formulations, Pharm. Res. 25 (2) (2008) 407-416.

[61] M. Pearton, V. Saller, S.A. Coulman, C. Gateley, A.V. Anstey, V. Zarnitsyn, J.C. Birchall, Microneedle delivery of plasmid DNA to living human skin: formulation coating skin insertion and gene expression, J. Control. Release 160 (2012) 561-569.

[62] H.L. Robinson, DNA vaccines: basic mechanism and immune responses (review), Int. J. Mol. Med. 4 (5) (1999) 549-555.

[63] A.K. Roos, F. Eriksson, J.A. Timmons, J. Gerhardt, U. Nyman, L. Gudmundsdotter, A Brave, B. Wahren, P. Pisa, Skin electroporation: effects on transgene expression, DNA persistence and local tissue environment, PLoS One 4 (9) (2009) e7226.
[64] N. Roxhed, P. Griss, G. Stemme, Membrane-sealed hollow MNs and related administration schemes for transdermal drug delivery, Biomed. Microdevices 10 (2008) 271-279.

[65] D. Sawamura, S. Ina, K. Itai, X. Mex, A. Kon, K. Tamai, K. Hanada, I. Hashimoto, In vivo gene introduction into keratinocytes using jet injection, Gene Ther. 6 (1999) 1785-1787.

[66] J.M. Song, Y.C. Kim, E.O.R.W. Compans, M.R. Prausnitz, S.M. Kang, DNA vaccination in the skin using miocroneedles improves protection against influenza, Mol. Ther. 20 (7) (2012) 1472-1480.

[67] D. Stoffler, B. Fahrenkrog, U. Aebi, The nuclear pore complex: from molecular architecture to functional dynamics, Curr. Opin. Cell Biol. 11 (3) (1999) 391-401.

[68] T. Suda, D. Liu, Hydrodynamic gene delivery: its principles and applications, Mol. Ther. 15 (2007) 2063-2069.

[69] T. Suda, X. Gao, D.B. Stolz, D. Liu, Structural impact of hydrodynamic injection on mouse liver, Gene Ther. 14 (2007) 129-137.

[70] C.E. Thomas, A. Ehrhardt, M.A. Kay, C.E. Thomas, Progress and problems with the use of viral vectors for gene therapy, Nat. Rev. Genet. 4 (5) (2003) 346-358.

[71] C.L. Trimble, M.P. Morrow, K.A. Kraynyak, X. Shen, M. Dallas, J. Yan, L. Edwards, R.L. Parker, L. Denny, M. Giffear, A.S. Brown, K.Marcozzi. Pierce, D. Shah, A.M. Slager, A.J. Sylvester, A. Khan, K.E. Broderick, R.J. Juba, T.A. Herring, J. Boyer, J. Lee, N.Y. Sardesai, D.B. Weiner, M.L. Bagarazzi, Safety, efficacy, and immunogenicity of VGX-3100, a therapeutic synthetic DNA vaccine targeting human papillomavirus 16 and 18 E6 and E7 proteins for cervical intraepithelial neoplasia 2/3: a randomised, doubleblind, placebo-controlled phase 2b trial, Lancet 386 (1008) (2015) 2078-2088.

[72] P. Van Damme, F. Oosterhuis-Kafeja, M. Van der Wielen, Y. Almagor, O. Sharon, Y. Levin, Safety and efficacy of a novel MN device for dose sparing intradermal influenza vaccination in healthy adults, Vaccine 27 (3) (2009) 454-459.

[73] V.V. Vlassov, M.V. Nechaeva, V.N. Karamyshev, L.A. Yakubov, Iontophoretic delivery of oligonucleotide derivatives into mouse tumor, Antisense Res. Dev. 4 (1996) 291-293.

[74] W. Walther, U. Stein, I. Fichter, P.M. Schlag, In vivo gene transfer of naked DNA into xenotransplanted colon carcinoma by jet injection, Langenbeck's Arch. Surg. 30 (2001) 69-72

[75] W. Walther, U. Stein, I. Fichter, K. Voss, T. Schmidt, M. Schleef, T. Nellessen, P.M. Schlag, Intratumoral low volume jet injection for efficient nonviral gene transfer, Mol. Biotechnol. 21 (2002) 105-115.

[76] P.M. Wang, M. Cornwell, J. Hill, M.R. Prausnitz, Precise microinjection into skin using hollow microneedles, J. Invest. Dermatol. 126 (5) (2006) 1080-1087.

[77] W. Wang, W. Li, N. Ma, G. Steinhoff, Non-viral gene delivery methods, Curr. Pharm. Biotechnol. 14 (1) (2013) 46-60.

[78] Z. Wei, S. Zheng, R. Wang, X. Bu, H. Ma, Y. Wu, L. Zhu, Z. Hu, Z. Liang, Z. Li, A flexible microneedle array as low-voltage electroporation electrodes for in vivo DNA and siRNA delivery, Lab Chip 14 (20) (2014) 4093-4102.

[79] D.J. Wells, Gene therapy progress and prospects: electroporation and other physical methods, Gene Ther. 11 (2004) 1363-1369.

[80] M. Wilke, E. Fortunati, M. van der Broek, A.T. Hoogeveen, B.J. Scholte, Efficacy of a peptide-based gene delivery system depends on mitotic activity, Gene Ther. 3 (12) (1996) 1133-1142.

[81] N. Wilke, A. Mulcahy, S.-R. Ye, A. Morrissey, Process optimization and characterization of silicon microneedles fabricated by wet etch technology, Microelectronics 36 (7) (2005) 650-656.

[82] G.L. Wilson, B.S. Dean, G. Wang, D.A. Dean, Nuclear import of plasmid DNA in digitonin-permeabilized cells requires both cytoplasmic factors and specific DNA sequences, J. Biol. Chem. 274 (31) (1999) 22025-22032.

[83] G. Yan, N. Arelly, N. Farhan, S. Lobo, H. Li, Enhancing DNA delivery into the skin with a motorized microneedle device, Eur. J. Pharm. Sci. 14 (52) (2014) 215-222.

[84] N.S. Yang, J. Burkholder, B. Roberts, B. Martinell, D. McCabe, In vivo and in vitro gene transfer to mammalian somatic cells by particle bombardment, Proc. Natl. Acad. Sci. U. S. A. (1990).

[85] W.H. Yu, M. Kashani-Sabet, D. Liggitt, D. Moore, T.D. Heath, R.J. Debs, Topical gene delivery to murine skin, J. Invest. Dermatol. 112 (1999) 370-375.

[86] G. Zhang, V. Budker, J.A. Wolff, High levels of foreign gene expression in hepatocytes after tail vein injections of naked plasmid DNA, Hum. Gene Ther. 10 (1999) 1735-1737. 